\title{
Perpetuating the 'Third World'? Evaluating knowledge production in the field of German Studies in an African context ${ }^{1}$
}

\author{
Carlotta von Maltzan \\ Department of Modern Foreign Languages, Stellenbosch University, South Africa \\ E-mail:vmaltzan@sun.ac.za
}

\begin{abstract}
This paper critically revisits and examines the seemingly outdated concept of the 'Third World' by tracing its historical origins with reference to the Three Worlds Theory, and investigates the reasons for the persistent implied or direct usage of the term in public and scientific discourse when referring to contexts which are typically considered to be underdeveloped. Of particular interest is the way in which knowledge production in German Studies functions in an African context which, as is argued, is influenced by complex relations that straddle the divide between a so-called "Western" and a so-called "African" perspective of the African continent, given that these perspectives are essentially determined by asymmetrical relations of wealth and power. To this end, the paper evaluates the self-perception of two academic journals in the field of German Studies published in West Africa and Southern Africa, respectively, by querying whether they participate in the postcolonial project of 'writing back' or rewriting colonialism in order to develop a new understanding of their participation in knowledge production.
\end{abstract}

Keywords: Third World, knowledge production, German in South Africa, Acta Germanica, Mont Cameroun

\section{Introduction}

What does it mean when we refer to or use the term "Third World", particularly within an African context and from an African point of view? More so, what does it mean when engaged in teaching a European and thus colonial language like German at a South African university, where we contribute to and participate in knowledge production within the country and within the continent? The question of knowledge production within the humanities and presumably also within other fields is complex and complicated. It is notably so in an African context because of preconceptions and assumptions made when we refer to Africa. A short anecdote serves to illustrate this point. A few years ago I attended a conference organised by the

1 This paper is based on a plenary paper entitled 'Dritte Welt'? Zum Selbstverständnis der Germanistik in (Sïd-)Afrika presented in German at the $15^{\text {th }}$ Congress of the Latin-American Association for German Studies (ALEG) in Curitiba, Brazil in 2014. 
Association for German Studies in Southern Africa ${ }^{2}$ hosted by Rhodes University ${ }^{3}$. During a break, a colleague from Cairo who had come to South Africa for the first time to participate in the conference remarked "I imagined Africa to be completely different". Upon further probing she elaborated. She mentioned the European flair of the town, remarked on the contemporary and well-preserved urban structures, thought that everything was so clean and well maintained, highlighted the comfortable, even luxurious, hotel, and was astounded by the efficiency she had come across. Last but not least, she had expected a more tropical landscape. Indirectly and inadvertently, the Egyptian colleague put forth a number of common Western assumptions, stereotypes and projections about the continent: Africa as disorder, disease, disaster, Africa as exotic, as the Dark Continent, and so forth ${ }^{4}$; unaware of the fact that of Grahamstown's approximately 70,000 inhabitants, about $80 \%$ speak isiXhosa. Needless to say, the Egyptian colleague did not see herself as an African, though Egypt after all belongs to a continent made up of what are now 55 African countries, following the independence of South Sudan.

There are historical, political and especially religious reasons why the north of Africa, which includes Mauritania, Morocco, Tunisia, Algeria, Libya and Egypt, is usually treated separately as the "Maghreb region" in public and Western discourse, while the remaining African countries are subsumed under the umbrella term of "Sub-Saharan Africa". From an African perspective, this sub-division of Africa is arguably based on assumptions of fundamental difference between the regions and their people. This assumption can be invalidated in so far as all African countries, except for Morocco, are now member states of the African Union (AU), launched on 9 July 2002 in South Africa to replace the Organisation of African Unity (OAU). Its main objective is to promote greater unity and solidarity between African countries and Africans. However, due to multilingualism in Africa - in some countries, more than 40 languages are spoken - and because of the European colonial past, one or more European languages are used as lingua franca(s). Both French, prominent in North and West Africa, and English, prominent in East and Southern Africa, are used as official languages by the AU; while Portuguese is used as the official language in Angola and Mozambique. It is thus clear how complex and diverse the African continent really is, as is the question of knowledge production, given Africa's colonial past and specific political and economic contexts.

\footnotetext{
${ }^{2}$ Conferences are organised bi-annually by the association Germanistenverband im südlichen Afrika (SAGV).

${ }^{3}$ Rhodes University, situated in Grahamstown in the Eastern Cape, was founded a little over 100 years ago and is the smallest University in South Africa, with approximately 6,000 students (cf. https://www.ru.ac.za/). As an international visitor, one can fly in via Johannesburg to the coastal city of Port Elizabeth. There one has to hire a car or take a shuttle to travel for about one and a half hours on small but well-maintained roads into the country's interior, past the Addo Elephant National Park, to reach what seems like a sleepy hollow, namely the small town of Grahamstown. It was founded in 1812 as a military outpost by Lieutenant-Colonel John Graham as part of the effort to secure the Eastern frontier of British influence in the then Cape Colony against the Xhosa, whose lands lay just to the East. The town's centre, the many and well-maintained colonial buildings which nowadays contain modern shops, restaurants and hotels, the nearby cathedral, several monuments and a museum are situated within walking distance of the Rhodes campus. They attest to Grahamstown's founding fathers and its colonial history. ${ }^{4}$ Interestingly, Bartholomäus Grill, a German journalist and author based in Cape Town, highlights this fact when he refers in his book on the role of soccer in Africa to consistent negative perceptions of South Africa in German media. He links these perceptions to the generally negative, even racist perception of Africa as a whole: „Man fragt sich, woran es liegt, dass Südafrika so oft eine derart schlechte Presse bekommt und wie eine Bananenrepublik dargestellt wird. Das hat mit der allgemeinen Wahrnehmung von Afrika zu tun, dem ' $K$ Kontinent', wie es in den Fernsehanalysen gern heißt. ,K'steht für Krisen und Konflikte, Kriege und Krankheiten, Kapitalflucht, Korruption und Kleptokratie. Viele Europäer halten diesen Erdteil für rettungslos verloren und glauben, es sei nur eine Frage der Zeit, bis auch dieses blühende Südafrika, das angeblich die Weißen ganz allein geschaffen haben, von den Schwarzen in den Abgrund gewirtschaftet wird" (Grill 2009:69).
} 
In her inaugural lecture, Christine Anthonissen (2015:4) outlined how, in the larger field of applied linguistics, critical linguistics could be taken simply as one of many theories within sociolinguistics, in that it investigates and is interested in explaining how language impacts on society, social structures, institutions and events, which in turn shape language. This investigation cannot be undertaken without looking at discursive structures and taking account of how power relations, or rather power hierarchies, and the way in which power is distributed determine how language functions. In fact, because critical linguistics draws on the insights of critical theory, which draws particular attention to the status of knowledge and thereby to the awareness that "the process of knowing is not to be severed from the historical struggle between humans in the world" (Anthonissen 2015:5), the question of ideology and our understanding of it in relation to culture is of particular importance. This is particularly the case because, as Thompson (1990) has pointed out, ideology is linked to mass communication. In other words, the question of knowledge production cannot be separated from the way in which discourses are constructed, given a particular ideological context and the manner in which this context often enables unequal power relations.

Taking this brief introductory overview as a point of departure, this paper has two aspects as its main focus. Firstly, it revisits the seemingly outdated concept of the 'Third World' by tracing its origins. Possible reasons for the continued usage of the term, including sweeping statements, persistent stereotypes, and projections of the German or Western imagination of Africa, both in literature on Africa and in public discourse, are also explored. For example, in many analyses in the German media of the soccer game between Ghana and Germany at the 2014 FIFA World Cup in Brazil, Ghanaian soccer players were consistently referred to as "Africans" instead of as "Ghanaians". Secondly, since Africa is still commonly viewed as belonging to the "Third World', the question arises as to whether such a perception influences knowledge production in German Studies practised within an African context, and if so, how. This takes account of the complex power relations between the so-called "mother country" of the language and the country in which it is taught as an academic discipline. Here one has to straddle the divide between a so-called "Western" and a so-called "African" perspective, since power relations are essentially determined by asymmetrical relations of wealth and power. To this end, I evaluate the self-perception of two German Studies journals published in West Africa and Southern Africa, respectively, by analysing their editorial policies and mission statements.

\section{The concept of the 'Third World'}

My deliberations about the relevance and the different meanings of the concept of the 'Third World' draw on the Indian literary theorist Aijaz Ahmad's (1992) book In Theory. In the first chapter, he critically reflects on the reasons for the emergence of a new research area called "Third World Literature" as part of the broader field of English Studies. He concludes that this delineation only makes sense within the context of metropolitan universities. However, universities in India were (and arguably are) dependent on American and British universities in as much as knowledge produced there would immediately take effect at home. According to Ahmad (1992:44), this relation of imperial dominance determines how Indian academics view their own literature and furthermore "shap[es] even the way [they] think of [them]selves". The pressure on the metropolitan university to discover new categories for the comprehension of cultural production in the 'Third World' therefore led directly to the perception that Indian literature and by implication knowledge production at Indian universities is inferior and therefore marginal. Ahmad also notes Indian universities' parasitic dependency on their 
Western counterparts. In his opinion, this is particularly obvious in English Studies at elite colleges in India, where academics try to outshine each other by obtaining higher degrees and teaching experiences overseas while trying to remain abreast of current discourse by publishing widely.

The inherent contradictions faced by academics at elite institutions in India as outlined by Ahmad in 1992 to some extent still hold true today; not only for an emerging economy like India, but also for other countries of the so-called "Third World". This is apparent when, despite the talk of globalisation, theoretical discourses are still largely imported from Western institutions to institutions in 'Third World' countries. This reliance on Western paradigms and thoughts is largely based on the assumption of a fundamental and generic difference between the West and the Other. This assumption is captured in public discourse in the postulation of a division between the global North and the global South, between the so-called "First World" and the so-called "Third World". Yet, after the global restructuring of the world that followed the collapse of the Berlin Wall in 1989, the need for mapping the world into three parts seems to be obsolete. However, a brief glance at the historical evolution of the Three Worlds Theory demonstrates that it still significantly affects our perception of academic contexts, institutions and abilities.

The Three Worlds Theory - its origins are mystified as Ahmad (cf. 1992:293) points out, as is the case with many misleading ideologies - can be traced back to Mao Zedong and the Chinese view at the time that, as imperialist superpowers, the USA and the Soviet Union should be categorised as belonging to the First World, while industrialised nations would make up the Second World. Although all of them were considered to be exploiting the Third World, industrialised nations were nevertheless seen to be dependent on the two superpowers. Within this context, China regarded itself as part of the Third World, and thereby saw itself as a developing country. As its spokesperson, it saw itself as being assigned with the task of fostering rapprochement between the Third and the Second Worlds as counterpoint to the hegemonic superpowers.

Another factor contributing to the founding myth of the Three Worlds Theory is a conference held in April 1955 in the Indonesian city of Bandung. The Bandung Conference, as it subsequently became known, was attended by the heads of state of 27 newly-independent Asian and African countries. Based on China and India's suggestion, the 'Five Principles for Peaceful Coexistence', published the previous year as a common declaration by both countries, were incorporated in modified form in a statement of ten principles adopted at the Bandung Conference. Although Ahmad (1992:295) concedes that they "certainly had a visionary edge" in that they included mutual respect for each other's territorial integrity, and highlighted mutual non-aggression and non-interference in each other's internal affairs as well as equality, cooperation and peaceful co-existence despite belonging to different political systems, "the declaration had an air of an informal undertaking that armies should not soon march against neighbours for acquisition of territory" (Ahmad 1992:295).

Another stated aim was the promotion of Afro-Asian economic and cultural cooperation, to oppose colonialism or neo-colonialism by any nation and to declare non-alignment in view of the escalating conflict between the Western and the Eastern bloc during the Cold War. Interestingly, within this context the Afro-Asian countries saw themselves as the "Third World" or the "Third Bloc". The Bandung conference can thus be considered an important step toward 
the founding of the Non-Aligned Movement in Belgrade in 1961. Because its members belonged to the economically weaker countries, the term "Third World" increasingly became synonymous with economically underdeveloped and poor countries. Nowadays, the term "Third World" is exclusively used in this sense.

The visionary beginnings of the ideational union of 'Third World' countries, first in Bandung and later in Belgrade to form a non-aligned movement within the context of the Cold War, led to a new mapping of the world by Western media, as Ahmad (cf. 1992:295f.) argues. The American sphere of influence became known as the "First World", not because the capitalist system was considered superior to the Soviet Union's communist system, but because the USA was considered to be more powerful. Its military alliances ranged from the North Atlantic Treaty Organisation (NATO) to the South Asian Treaty Organisation (SEATO), and it had a far more global reach than the USSR. The USSR and its allies in the Warsaw Pact were technologically less well-equipped, and were therefore considered as the 'Second World'. In contrast, the countries of the Third World were visualised by the Western media as a bloc which could act as a buffer between the two superpowers and preserve peace. However, this ideational mapping of the world, both in the media and in academic writing, did not consider that more than half of the founding members of the Third Bloc were in effect reliant on one of the superpowers, rather than belonging to the non-aligned states.

This brief and of necessity rather sketchy outline of the historical circumstances that led to the circulation of the Three Worlds Theory and the use of the term "Third World" demonstrates that, as Ahmad points out, it cannot be considered as arising from a mass movement formed in opposition to the state - in contrast to other theories of social emancipation such as movements for democratic rights, the women's movement, and anti-colonial nationalisms. Rather, its origins can be directly traced to ideas conceived by heads of state. It was subsequently disseminated by groups of or individual states. From the beginning, therefore, the term "Third World" was never a purely descriptive category referring to geographically-defined regions or a relation to one of the imperialist superpowers. Instead, and paradoxically, it always had political connotations. Nationalistically-motivated heads of state such as the Indian president Nehru saw the use of the concept of the 'Third World' as a path to contain communism. In its Soviet variant, it meant the toleration of states like Egypt under the leadership of Nasser, who attempted to introduce an Arabic form of socialism. In its Maoist version, the concept of the 'Third World' was seen from yet another fundamentally different angle, namely as a location of possible resistance, and as an alternative to withstand interference and encroachment by the First and the Second Worlds.

After the fall of the Berlin Wall in 1989, more explanatory models that can be traced to the Three Worlds Theory emerged. Worth mentioning is the most common one, based on the assumption that in the new political world order since the 1990s, there are basically two worlds. On the one hand, one finds the essentially 'white' and industrialised world, and on the other hand, one finds the 'non-white' and non-industrialised world. In other words, what were formerly regarded as the First and Second Worlds are now viewed in contrast to the postcolonial Third World. Needless to say, this explanatory model is overtly racist, and like the Three Worlds Theory, is based on several fallacies and incorrect assumptions. On the one hand, mapping and dividing the world into several blocs suggests homogeneity or homogenous unity of several groups or nations regarding their interests. On the other hand, all theories mentioned seem to be based on the idea that something like a 'transnational nationalism' exists, based 
perhaps on the same religious affinity, on perceived racial difference, or on shared poverty, to name but a few possibilities. What all these explanatory models, which are based on binary and monolithically-conceived oppositional structures, fail to take into account is that in the global system of classification, hierarchical structures are at the core of determining how and why this classification is done in the first place. These hierarchical structures also seem to influence the way in which the academic enterprise is viewed, both in teaching and in research. Yet it would not be prudent to ignore country-specific contexts. A country and therefore also its academic environment are ultimately fundamentally determined by the strength or weakness of the country's economy. For this reason, the academic environment of South Africa cannot truly be compared to the one in Burkina Faso, to name but one example in Africa.

Therefore, when someone like Edward Said, in his ground-breaking 1977 study on Orientalism, celebrates the pioneering and rejuvenating spirit of the Bandung Conference of 1955 in a lessthan-nuanced manner and yet manages to lay the foundations for what became known as "postcolonial theory", one should not lose sight of the fact that postcolonial theory is exceptionally useful when analysing processes of colonisation, ongoing decolonisation and recolonisation. However, postcolonial theory as well as Said's text is not free of contradictions. He freely acknowledges this double-bind in his own knowledge acquisition when he states much later: "So you grow up learning the language and culture and history of this place that was your master and, at the same time, are forced to concede that, although you were learning it, you could never be part of it" (Said 2002:263f.) And, as Gayatri Chakravorty Spivak (1999:39) has pointed out in Imperatives to Re-Imagine the Planet: "The freedom to be contradictory is essential". Both Said and Spivak thus highlight the contradictory linguistic reality of a dominant discourse when it is engaged in by members of the dominated language group and culture. This brings me to the second part of this paper, in which the parameters of knowledge production in an African context are explored by critically examining the editorial policies of two scientific journals in the field of German Studies and the contradictions they face.

\section{Knowledge production in the field of German Studies in an African context}

To contextualise the working environment within an African context, which also affects the production of scientific journals in the field of German Studies, it is useful to reflect on the numbers of learners of German outside of Europe and the Commonwealth of Independent countries. As shown by the graph below (see Figure 1) detailing trends between 1983 and 2010, all regions have in common that the teaching of the subject of German has never played a significant role; the total number of learners of German remaining below 20\%. It is however noteworthy that while learner numbers dropped drastically in Asia and remained more or less the same in North America, they increased fivefold in the Near and Middle East, by $140 \%$ in South America, and four and a half times in Africa over the given time period. At first glance, this seems to be a positive development for the field of German Studies as far as Africa is concerned.

While the scientific study of the German language, of German literature and the Germanspeaking countries, namely Germany, Switzerland and Austria, at tertiary institutions on the African continent is highly complex and differentiated and does not allow for sweeping statements on the state of German Studies on the whole continent to be made, many German Departments throughout the continent face similar problems, since their graduates have 
difficulty in finding employment. This has led to adjustments in the tertiary curricula of some countries like Senegal and Uganda, where German Studies has been professionalised through the introduction of translation and interpreting courses and the inclusion of Wirtschaftsdeutsch, or German for economic purposes. In South Africa, German as a discipline offered at tertiary institutions has been on the decline since the early 1990s, at least at first glance. Whereas German was offered at 15 South African universities in 1994, the number has now declined to 9. ${ }^{5}$ The closure of German or Foreign Language departments as a whole, which occurred at e.g. the University of KwaZulu-Natal in 2015, has various motivations, ranging from dwindling student numbers and rationalisation to general downsizing in the humanities. Surprisingly, the overall numbers of students taking German in South Africa remained stable during the same time period, in that some German sections actually had an increase in student numbers despite a general downsizing in staff (cf. von Maltzan 2009:212). Since reduced staff numbers did not allow for a reorientation of programmes offered in South Africa by for example including Wirtschaftsdeutsch, the reorientation of some German programmes in other African countries is presumably rooted in the need for legitimising the subject within the context of higher education that can contribute to the economic improvement of the country through the employability of its graduates, a development which is probably not limited to the African context or continent.

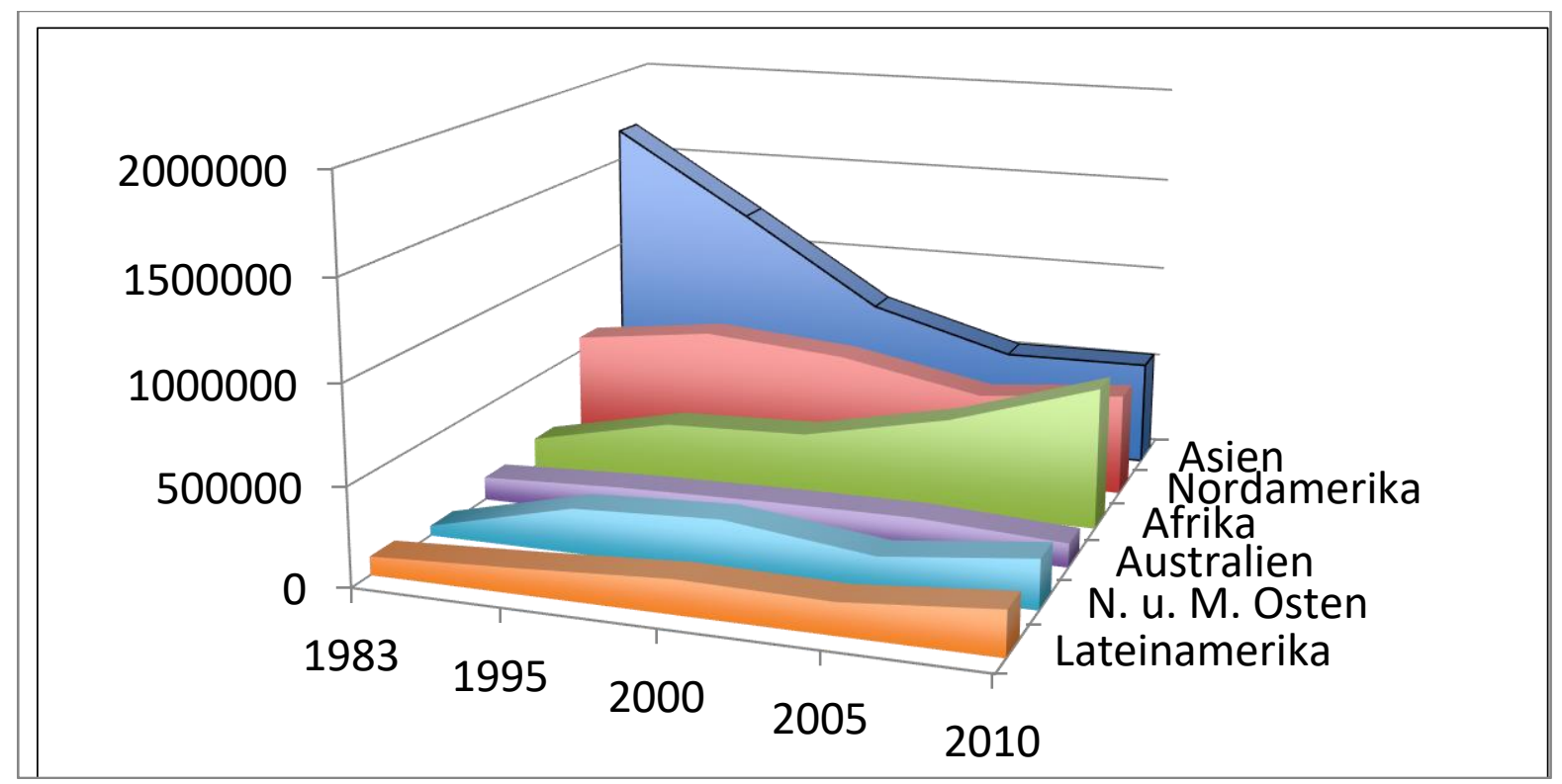

Figure 1: Learners of German between 1983 and 2010 in Asia (Asien), North America (Nordamerika), Africa (Afrika), Australia (Australien), the Near and Middle East (N. u. M. Osten), and South America (Lateinamerika). Source: StADaF e Netzwerk Deutsch.

\footnotetext{
${ }^{5}$ The following universities have retained German: University of Cape Town, University of the Western Cape, University of Stellenbosch, Rhodes University, University of the Free State, University of Zululand, North-West University (Potchefstroom), University of the Witwatersrand, and University of Pretoria. Since 1994 German sections (or whole Foreign Language departments) were closed down at the following universities: University of South Africa, University of Limpopo (University of the North), Nelson Mandela Metropolitan University, University of KwaZulu-Natal (Durban), University of KwaZulu-Natal (Pietermaritzburg), and University of Johannesburg.
} 


\section{Knowledge production and self-perception: Two African journals in German Studies}

Evidence of the need for legitimation can be found on another level as well, namely in the field of research in German Studies. This field of research is analysed in what follows, firstly by investigating the editorial policy of the West African journal Mont Cameroun, followed by a similar analysis of the Southern African journal Acta Germanica. In both contexts academics and researchers are confronted with a double-bind: On the one hand, they are faced with the possible perception within their country of engaging with a language and its literature which has colonial roots and is driven by Western paradigms. On the other hand, they are faced with the pressure to 'measure up' to the research that is conducted on the language and its literature in the German-speaking countries. It is perhaps for this reason that in West Africa or the Francophone countries, academics in the field of German Studies tend to refer to themselves and their research as Afrikanische Germanistik ('African German Studies') instead of for example Germanistik in Westafrika ('German Studies in West Africa'). Inherently, and perhaps inadvertently, West African academics thus claim that their practice and research is representative of German Studies in the whole of Africa, thereby ironically repeating a Western practice and perception that does not distinguish between different African regions and/or countries and disavows differences, despite whatever commonalities there might be. This inherent contradiction in the self-perception of their work is also apparent in the foreword by Albert Gouaffo and Salifou Traoré to the first edition of the bilingual (French and German) West African journal Mont Cameroun, which was launched in 2004 and carries the subtitle African journal for intercultural studies on the German-speaking countries:

In francophone Africa German has been taught since the 1960s. Within the context of European-African contact this subject was imported to Africa. In the 1970s German became a subject at the newly-founded African universities. During the 1980s the status of this national discipline was interrogated within an African context where the idea of 'nation' in a European sense is absent. The general consensus was that African German Studies needed to have a practical component when educating future teachers and academics. This need by now has been met. Today this discipline has to be regarded within the context of globalisation where Africa is remarkably absent when taking account of international discussion forums or decision-making bodies. In this sense Africa is faced with titanic challenges which need to be met.

Gouaffo and Traoré (2004:5, my translation)

Two aspects in the foreword are noteworthy: Firstly, the reference to "African German Studies" fails to acknowledge that there might be regional differences in the state of higher education across the continent. Secondly, and perhaps more importantly, the editors make the legitimate observation that Africa is largely excluded from the international academic scene. Considering this absence, they seek to define the journal's profile by listing three ways in which German Studies could contribute to change:

1. African German Studies has to take a much stronger stand than before. To be an academic and a researcher means to take a definite position and to defend it.

2. African German Studies needs to highlight and rectify its avant-garde role in multi- and intercultural research by providing postcolonial answers similar to the diaspora in the 1930s and 1950s. 
3. The developmental potential of German Studies as a science in Africa should not only be posited, as was the case in the past, but should be proven through the implementation of curricula that are relevant in practice and by empirically conducted evaluations.

Gouaffo and Traoré (2004:6, my translation)

The editors of Mont Cameroun's first edition thus outline paradigmatically the challenges German academics in a West African context can and want to face. Implicitly, they also position themselves and their work within the intellectual tradition of the Négritude and its initiators, such as the Martinican poet Aimé Césaire; Léopold Sédar Senghor, who later became president of Senegal; and finally Léon Damas of French Guiana. However, despite the reference to this tradition and to postcolonial discourse, African German Studies and a new African consciousness, academic and research exchange is paradoxically not sought out within Africa or with other regions of the so-called "Third World", but is still conceptualised according to European models. This is evident when we read further:

Research outputs, mostly the result of difficult working conditions, are often not readily accessible to Africans as they are published in journals outside of Africa. Therefore, when we founded the research group Études Germane-Africaines, we decided to solve this dilemma by launching the African journal Mont Cameroun, which we see as a discussion forum which from an African point of view together with other African journals formulates and discusses pertinent issues within a global context. We are able to do this with the aid of and in cooperation with partners from Europe.

Gouaffo and Traoré (2004:7, my translation)

While the first issue of Mont Cameroun still highlights European partners and research exchange with partners from German-speaking countries, this has now changed. In the last decade, research cooperation between West and Southern African regions and publication of articles in each other's journals have increased dramatically. The reason for this change can be partially attributed to the founding of the Association for German in Sub-Saharan Africa (GAS) in 2006, which claims members of German departments from Cameroon, Togo, Senegal, Côte D'Ivoire, Mali, Burkina Faso and Benin. Subsequently, GAS put out feelers to researchers in German in the Southern African region. This resulted in the launch of the first joint conference between GAS and the Association for German Studies in Southern Africa (SAGV), which took place at Stellenbosch University in 2010 on the occasion of the first FIFA World Cup to take place in Africa. The conference was devoted to the topic "Sport, games and passion: African and German perspectives", and resulted in a joint book publication (von Maltzan 2012). A second joint conference took place three years later in Yaoundé in Cameroon, devoted to the topic "Memory and colonialism in Africa and Germany". It was then decided to have joint conferences and publications every three years. The next one in 2019 will also include the Association for German Studies in Eastern and Central Africa (GOZA), which was launched in 2015.

German Studies in Southern Africa has a very different history to that of German Studies in West or East Africa. In Southern Africa, German as a subject was introduced 60 years earlier than in West Africa, when in 1880 the so-called "South African College" established the first professorship for Modern Languages including German (von Maltzan 2010; Kussler 2001). It can therefore look back at the longest tradition on the African continent. The SAGV, however, 
was founded much later, namely in 1966 , when it also launched two journals ${ }^{6}$. The first is Deutschunterricht in Südafrika, which was originally aimed at schoolteachers and provided teaching material and lesson outlines. Nowadays this non-accredited journal is available electronically and serves as a discussion forum for the subject of German at both schools and tertiary institutions ${ }^{7}$. The second is the yearbook Acta Germanica, which is subtitled German Studies in Africa. Naturally, the profile of the journal has changed tremendously in the past 50 years. While the first 10 volumes were published in Cape Town and subsequent ones in Windhoek in Namibia, it was decided in 1982 to shift its publication to Peter Lang in Frankfurt, Germany, thereby signalling the desire to become an equal discussion partner on the German Studies scene in Europe. Since 2011, the journal has had an African edition as well, while Peter Lang has retained distribution rights for all territories except Africa. Acta Germanica is bilingual and accepts contributions in German and English, thus adhering to guidelines similar to those of Mont Cameroun, where articles in either German or French are accepted. In contrast to the editors of Mont Cameroun, the editors of Acta Germanica only recently reflected on the fact that the journal must be considered an African journal, by adding an editorial policy in 2010 that states that the journal subscribes to being a "scientific forum which presents and takes special account of (South) African perspectives on current debates and themes pertaining to German literary and cultural studies, critical theory, and the teaching of German as a foreign language" $"$. This change in direction acknowledges a subtle change regarding the topics tackled in the journal's articles, in that Africa and African issues, including the South African academic environment, have increasingly become a subject of debate in the journal. This is borne out by a brief overview of the journal's contributions over the last five decades. While articles published until the early 1980s dealt mainly with topics and themes that largely coincided with research interests in the German-speaking countries, it is noteworthy that since 1984 there has been a noticeable increase in research contributions related to the African context; a direction that the journal now fully subscribes to in that it invites contributions to a section entitled "Writing Africa". Contributions in this section would typically not only explore the influence of the German colonial past on German literature, but also consider imaginations of Africa from precolonial times to the present. Since the 1990s, the question of the Other has been increasingly debated within the journal. In addition, a critical reflection on the status of the subject of teaching German at schools and in higher education in South Africa as well as within the continent has become increasingly important, mainly in response to the increased restructuring of South African universities and the downsizing of staff, particularly in the humanities.

\section{Areas of contestation}

It is clear that despite completely different working conditions and institutional frameworks, many synergies between research approaches in German Studies in West and Southern Africa can now be detected, especially in as much as researchers seek to confidently locate their findings both within an African and an international context. Such attempts at localisation, not only of one's own research but also of the research object, are not always uncontested. This becomes apparent when one looks at the case of the philosopher Anton Wilhelm Amo, whose identity as either African or German has been the cause of disputes between African and German researchers in the field of German Studies. Amo spent about 30 years in Germany between 1707 and 1746, and is considered a philosopher of the Enlightenment. Born in Axim

\footnotetext{
${ }^{6}$ The association now has members from South Africa, Namibia, Zimbabwe, Mozambique and Madagascar.

${ }^{7}$ For details see the website at http://www.sagv.org.za/publ_dusa.htm

${ }^{8}$ For details see the website at http://www.sagv.org.za/publ_acta-ausrichtung.htm
} 
at the Gold Coast, now Ghana, he was captured as a child by slave traders and sold to Duke Anton Ulrich of Braunschweig-Wolfenbüttel, who later encouraged him to study in Wittenberg and Halle. In 1734 he defended a philosophy dissertation at the University of Halle in Saxony, written in Latin and entitled "On the Impassivity of the Human Mind". Besides Latin he knew Greek, Hebrew, French and Low as well as High German:

A dedicatory letter was appended from the rector of the University of Wittenberg, Johannes Gottfried Kraus, who praised 'the natural genius' of Africa, its 'appreciation for learning', and its 'inestimable contribution to the knowledge of human affairs' and of 'divine things'. Kraus placed Amo in a lineage that includes many North African Latin authors of antiquity, such as Terence, Tertullian and St. Augustine.

Smith (2013)

West Africans have the highest regard for Amo. In Senegal, a German journal is named after him, while Cameroonian philosopher Jacob Emmanuel Mabe, who now teaches philosophy in Germany, considers him to be the first great African philosopher of international importance and recently published a book in his honour (Mabe 2014). Which cultural realm does Amo therefore belong to? German academic Ottmar Ette (2014:151) believes that given his reterritorialisation it is too simplistic to simply regard him as an African and thereby to reduce his identity to one aspect only. Instead, Otte argues, Amo represents a philosophy of the Enlightenment located between Europe and Africa. However, the case of Amo, or rather the way in which his identity is ascribed, demonstrates a problem that arises precisely because of the dominant perception of what is considered to be the 'Third World' today. It is not uncommon for academics in the field of German Studies, and perhaps generally for researchers from all countries of the so-called "Third World", to court and even fight for recognition of their work in an international context and in the German-speaking countries. It seems therefore that the desire and demand for recognition is the cause for the claim that Amo is a true "African" philosopher. According to Aleida Assmann (2013:170f.), the need for recognition arises from what Dipesh Chakrabarty (2007) calls "historical wounds" resulting from the interweaving of history and memory. This is preceded by a centuries-long politically-legitimated lack of recognition of one group by another by the refusal to acknowledge their equal worth. In the hierarchical scale, this state of affairs is upheld by the violent establishment and maintenance of relations of ownership and communication, as well as through difference as a codified marker.

\section{Conclusion}

Considering the potential paradoxical situation of academics and researchers working in the field of German Studies in Africa, where of necessity it is simply not sufficient to work within a Western or European framework of reference when engaging in the analysis of German language and literature, it must be kept in mind that everyone who is part of the academy in an African context and thereby part of the so-called "Third World" is faced with a challenge, namely to recall and own the original meaning of the concept 'Third World' despite the contradictions that might arise. That would mean that in scientific and critical discourse, as was argued at the outset, it is necessary to highlight and strengthen a relational perspective as a real alternative while withdrawing from violent representations that invoke difference as absolute. In the same vein, it would be important to show the impossibility of writing a history of the West to the exclusion of a history of the colonised countries, and vice versa. In other words, as 
Anthonissen (2015:8) states, it is imperative, as critical theory propagates, to "gain an understanding of how society is (also discursively) reproduced and transformed, and what the relationship is between individuals [and] society", and in this case between the researcher and his/her academic environment. In practical terms, this could mean for example that in the field of German Studies, one could look at ways in which it is possible to connote the term "Third World" positively, for example by seeking to engage in cooperative projects along a SouthSouth axis such as Brazil - South Africa - India; along an axis therefore which traces commonalities and similarities rather than difference. This direction is already pursued in sociolinguistics and English Studies, to name but a few. Of course, this new direction would not preclude a South-North dialogue. Rather, this new perspective would allow for German Studies in Africa to be viewed as an ensemble of entanglements, despite the many contradictions it faces in teaching and research.

\section{References}

Ahmad, A. 1992. In theory. Classes, nations, literatures. London, New York: Verso.

Anthonissen, C. 2015. Multilingual spaces as contact zones: 'Critical' things we need to know about critical linguistics. Available online:

http://www.sun.ac.za/english/Inaugurallectures/Inaugural\%20lectures/InauguralLectureProfA nthonissen.pdf (Accessed 2 November 2015). pp. 1-13.

Assmann, A. 2013. Das neue Unbehagen am der Erinnerungskultur. Eine Intervention. München: C.H. Beck.

Chakrabarty, D. 2007. History and the politics of recognition. In K. Jenkins, S. Morgan and A. Munslow (eds.) Manifestos for history. London and New York: Routledge Chapman \& Hall. pp. 77-87.

Ette, O. 2014. Anton Wilhelm Amo - Philosophieren ohne festen Wohnsitz. Eine Philosophie der Aufklärung zwischen Europa und Afrika. Berlin: Kulturverlag Kadmos.

Gouaffo, A. and S. Traoré. 2004. Vorwort. Mont Cameroun. Afrikanische Zeitschrift für interkulturelle Studien zum deutschsprachigen Raum 1: 5-8. Available online: http://www.mont-cameroun.com (Accessed 15 August 2015).

Grill, B. 2009. Laduиииита! Wie der Fußball Afrika verzaubert. Hamburg: Hoffmann und Campe.

Kussler, R. 2001. Deutschunterricht und Germansitikstudium in Südafrika. In G. Helbig (ed.) Deutsch als Fremdsprache. Ein internationales Handbuch, vol 2. Halbband. Berlin and New York: De Gruyter. pp. 1609-1619.

Mabe, J. E. (ed.) 2014. Warum lernt und lehrt man Deutsch in Afrika? Autobiographische Ansichten und didaktische Erfahrungen. Festschrift zu Ehren von Anton Wilhelm Amo. Nordhausen: Verlag Traugott Bautz. 
Thompson, J.B. 1990. Ideology and modern culture. Critical theory in the era of mass communication. Cambridge, UK: Polity.

Said, E. W. 1977. Orientalism. London: Penguin.

Said, E. W. 2002. Power, politics and culture. Interviews with Edward W. Said (ed. G. Viswanathan). New York: Vintage.

Smith, J.E.H. 2013. The Enlightenment's 'race' problem, and ours. Available online: http://opinionator.blogs.nytimes.com/2013/02/10/why-has-race-survived/? r=0 (Accessed15 August 2015).

Spivak, G. C. 1999. Imperatives to re-imagine the planet / Imperative zur Neufindung des Planeten (ed. W. Goetschel). Vienna: Passagen.

Von Maltzan, C. and D. Simo (eds.) 2012. Sport, Spiel und Leidenschaft. Afrikanische und deutsche Perspektiven. Paderborn: Wilhelm Fink.

Von Maltzan, C. 2009. Sprachenpolitik und die Rolle der Fremdsprachen (Deutsch) in Südafrika. Stellenbosch Papers in Linguistics PLUS 38: 205-214.

Von Maltzan, C. 2010. Deutsch in Südafrika. In H-J. Krumm, C. Fandrych, B. Hufeisen, C. Riemer (eds.) Deutsch als Fremd- und Zweitsprache. Ein internationales Handbuch. 2. Halbband. Berlin and New York: De Gruyter Mouton. 